Journal of Economics and Behavioral Studies

Vol. 6, No. 9, pp. 735-747, September 2014 (ISSN: 2220-6140)

\title{
Agricultural Extension Service and Input Application Intensity: Evidence from Ethiopia
}

\author{
Kidane Mariam Gebregziabher \\ Risk Management and Banking, University of South Africa, South Africa \\ kg9676@gmail.com
}

\begin{abstract}
This paper examines factors that influence agricultural input adoption in the northern part of Ethiopia. Using a 730 households survey data set, a Tobit model is estimated to explain the factors that influence farmers' decision to adopt modern inputs or not. The factors found to significantly influence included: plot size, oxen ownership, gender, age and literacy status of the household head, adult labor force, total non-farm income, extension service and location variables. The results confirm the adoption theory.
\end{abstract}

Keywords: input intensity, technology adoption, Tobit, Ethiopia

\section{Introduction}

Ethiopia is one of the oldest nations where agriculture has been practiced for some 11,000 years (Davidson, 1960, cited in Abate, 2007). According to Abate (2007), cereal crops such as finger millet and teff (Eragrostistef, teff) were first domesticated and used by Ethiopian farmers around five and six thousand years ago. Since the institutionalization of agricultural extension service by the Ethiopian government in the1930s, various strategies have been made to promote wider use and improve access to agricultural inputs such as fertilisers, manure and improved seeds, against a background of low rates of fertiliser and hybrid seed adoption among smallholder farmers (Abate, 2007). In the past several decades the government has invested substantially in the promotion of modern technologies in the agricultural sector, including the provision of subsidies for agricultural inputs. Currently, except the subsidies for agricultural inputs, there are considerable public sector investment in integrated rural development projects which have introduced a range of services, including extension services and rural credit facilities (Kidanemariam, 2013). Ethiopia has ample resources for agriculture. Out of the total land size of 111.5 million hectares (ha) of land, 74 million ha is estimated to be suitable for agriculture (mostly located in the low lands which are less accessible). However, only 13 million ha are being used which is less than 20 per cent of the available land (Davis et al., 2009).Water resources are also plentiful in much of the country, with $1471 \mathrm{~m} 3 /$ year/capita and of the irrigable land potential of 2.7 million hectares, only 11\% actually is irrigated as of 2009 (FAO, 2014). Ethiopia's livestock resources are among the top in the world, at least in terms of quantity (Davis et al., 2009).According to Tomich et al. (1995), Ethiopia is a country of abundant rural labour force that can be deployed and at an early stage of structural transformation.

The country has a fertilizer consumption level of $20 \mathrm{~kg} / \mathrm{ha}$ NPK (Nitrogen-N, Phosphate- $\mathrm{P}_{2} \mathrm{O}_{5}$, and Potash- $\mathrm{K}_{2} 0$ ) which is $16 \%$ lower than the Africa average, not to mention the world average As a result, the average productivity per ha for cereal remains at 18.3 quintal/ha, a little bit higher than the African Average (14.8 quintal /ha) (FAO, 2014). Henao \& Baanante (1999) estimated a negative balance of NPK (Nitrogen-N, Phosphate- $\mathrm{P}_{2} 0_{5}$, and Potash- $\mathrm{K}_{2} 0$ ) for the whole of Sub-Saharan Africa (SSA), with the exception of South Africa. While an average replenishment rate of $40-80 \mathrm{~kg} \mathrm{NPK} \mathrm{ha}^{-1}$ is required to maintain the production level of agricultural production in SSA, the actual replenishment was less than $10 \mathrm{kgNPK}^{-1}$, indicating an annual average depletion rate of above $50 \mathrm{kgNPK}^{-1} \mathrm{~h}^{-1}$ (Henao \& Baanante, 1999). According to available data, yield reductions due to erosion ranges from $2 \%$ to $40 \%$, with a mean of $8.2 \%$ for the continent and $6.2 \%$ for subSaharan Africa (SSA). Moreover, if accelerated erosion continues unabated, yield reductions by the year 2020 may be $16.5 \%$ for the continent and $14.5 \%$ for SSA (Lal, 1995). Ethiopia, in view of its mountainous physical features and traditional agricultural system, the situation cannot be different from stated trend, if not worse. Based on, the head count poverty measurement index using $\$ 2$ and $\$ 1.25$ (purchasing power parity), 66\% and $31 \%$ of the total population lives under poverty line respectively (FAO, 2014). According to United Nation's (2004) projection, the current world population of 7.2 billion (in 2014) will reach 8 billion by 2020 
and 9.4 billion by 2050. Similarly, the current population of Ethiopia ( 94 million) is projected to reach 140 million by 2050 .

It is against this background, at a time when many governments in Africa curtailed support to the agricultural sector, the government of Ethiopia instituted a policy of Agricultural Development-Led Industrialization (ADLI). As a result, in the past two decades, the government has committed an average of 16.8 per cent (2008-2011) of the government budget to the sector (FAO, 2014; Davis et al., 2009); which is one of the highest in the continent. Agriculture generates $46 \%$ of the GDP and $90 \%$ of the foreign exchange earnings. Ethiopia is the second most populous nation in Sub-Saharan Africa with a population of about 94 million of which 76\% are rural (Spielman et al., 2010; FAO, 2014; Federal Democratic Republic of Ethiopia, 2002). Despite the massive effort by the government and others involved in the development processes of the country to end poverty in rural areas, it is being undermined by the declining and extreme land shortages in the highlands, where per capita land area has fallen from 0.5 ha in the 1960 s to only 0.2 ha by 2008 , low productivity of food production (with cereal yields averaging around $1.8 \mathrm{ton} / \mathrm{ha}$ ), recurrent droughts and variable rainfall, and, as a consequence, high variability in agricultural production (Spielman et al., 2010). In addition to the critical land shortage problem, soil erosion/land degradation and the resultant micro-nutrient depletion are the most critical problems in Africa in general and in Ethiopia in particular. Annually Ethiopia loses over 1.5 billion tons of topsoil from the highlands through erosion (Hurni, 1988; Taddese, 2001).

Against this background, the objective of this paper is twofold. First, its aim is to estimate how extension service impacted households' behaviour in the adoption of modern agricultural inputs, viz.: inorganic fertilizer and improved seeds varieties in the research areas, in the northern part of Ethiopia. Second, it aims to identify (if any) factors influencing household adoption/non-adoption behaviours. Identifying variables that affect the adoption decision at household level can provide policy makers with information to design programmes and introduce cost-effective technology dissemination program measures and long-run development strategies in research and technology generation capacity, so as to address farm productivity in smallholder households. Furthermore, it helps to streamline extension services so as to make them demand driven and participatory. This in turn is expected to affect the human resource development of the extension and research programs. Understanding the factors that affects farmers' adoption decision can guide policy makers' budget priority settings and allocations. Third, to address the endogeneity problem observed in most studies (see literature review below); appropriate estimation techniques such as the exogeneity test for the endogenous variable (extension service) are used to improve the efficiency of model estimation. The rest of the paper is structured as follows. Section 2 presents a brief review of relevant literature; section 3 discusses the methodology; section 4 presents results and discussion; and section 5 concludes.

\section{Literature Review}

Our understanding of the factors that affect the adoption of fertilizer and hybrid seed technology assists in addressing the policy failures experienced in the area of technology promotion in Ethiopia. There have been various studies on the technology adoption process (Rogers, 1962; Rogers, 1983; Zeller et al., 1998) and the factors affecting the adoption decision (Feder et al., 1985). It is very common to find in the literature of agricultural technologies adoption household, farms, social and economic variables as explanatory variables affecting the adoption process, the decision choice and as well as the intensity of adoption, and the impact of these on adopters' welfare. Among these variables are input price (cost of adoption), plot size, and human capital (Caswell \& Zilberman, 1985; Feder et al., 1985; Dinar \& Yaron, 1990). Feder et al. (1985) noted that farmers with bigger land areas are more likely to adopt irrigation equipment, tractors and modern variable inputs. Abdulai and Huffman (2005) found that human capital positively affect the decision to acquire information and to adopt a technology. Furthermore, households' asset holdings, household characteristics, and perception of need are also used to model the technology adoption decision (Adeoti, 2009). In general it has been found that (1) an increase in the price or cost of technology reduces a farmer's likelihood to adopt (Caswell \& Zilberman, 1985; Feder et al., 1985); (2) households with larger farm size are more likely to adopt (Rahm \& Huffman, 1984; Putler \& Zilberman, 1988; Feder, 1980); (3) an adopter's human capital endowment variables such as age, gender, education, and experience affect positively the likelihood to adopt (Huffman, 1977; Rahm \& Huffman, 1984; Putler \& Zilberman, 1988); and (4) social capital (membership in social 
network), and institutional capital (access to institutional services such credit and extension service) are also likely to induce farmers to take some risks and adopt technologies.

However, according to a review made by Feder et al. (1985) and recently by Sunding \& Zilberman(2001, cited by Doss, 2006), they recommended five focus areas on which future technology adoption studies should focus: (i) examining the intensity of adoption (not just dichotomous choices); (ii) addressing the simultaneity of adoption of different components of a technology package; (iii) analysing the impact of incomplete markets and policies on adoption decisions; (iv) contextualizing adoption decisions within social, cultural and institutional environments; and (v) paying attention to dynamic patterns of changes in landholdings and wealth accumulation among early and late adopters. Yet some of the concerns raised by Feder et al. (1985) remain unanswered (Doss, 2006); and in addition to that, in most cases the issue of endogeneity is completely ignored in their model specification. For instance, Chirwa (2005) studying the adoption of fertilizer and hybrid maize in Malawi, and Fufa \& Hassan (2006) in Ethiopia, although they tried to address the simultaneity of adoption of different components of technology packages (fertilizer and hybrid maize), their small size sample (156 and 100 adopter and non-adopter households respectively) was too small to be expected to capture how adoption varies across different agro ecological zones. Moreover, Chirwa (2005) examined adoption as choice variable instead of percentage of total area covered by fertilizer, improved seeds or total amount of spending on improved inputs (intensity). A study in Ethiopia by Shiferaw \& Tesfaye (2006), Abebe et al. (2013), and Alene et al. (2000)focused on the effect of fertilizer on improved potato, and improved maize adoption respectively, and ignored the joint decision of adopting both fertilizer and hybrid seed technologies together. Hence, these studies assumed that there was no interdependence between the decisions to adopt fertilizer and hybrid seed technologies.

Even those studies which considered the possibilities of the joint decision such as Shiferaw \& Tesfaye (2006), Abebe et al. (2013), and Alene et al. (2000) are based on a very simplistic assumption. For instance, a study on improved maize variety will categorize a farmer as a non-adopter if the farmer found to be non-adopter of the crop; without controlling for the adoption status for other crops. The farmers who do not choose (for various reasons) the improved maize variety can choose potato, wheat or any other crop and still can be considered as non-adopters in the maize adoption study, and the same is true for the other crops. Hence, in this regard the analysis of variables vis-à-vis the adoption decision and the interpretation of results could be totally wrong. Policy makers are interested to know how farmers are reacting to the menu of improved crop varieties listed in the extension service, instead of a single crop. Hence, farmers are working under very diverse biophysical features (soil quality, slope, temperature, etc.) even in a very small locality. Hence, without full control of farmers' adoption of other crops, to categorize a household as non-adopter misleads policy makers. This study attempts to address the simultaneity of adoption of different components of a technology package (of land covered by improved seed, fertilizer, and total value of improved technology input purchased), use sample households drawn from three agro-ecologies, in analysing the adoption

decision of households controlled the adoption of other crops, and tried to minimize the problem of edogeneity not observed in most studies.

\section{Methodology}

Area description and Data sources: We conducted a household survey in the period May - June 2009 in the northern part of Ethiopia (in the Geba Catchment in Tigray region). The Geba catchment is predominantly a rural area and the large majority of people are smallholder farmers. The typical farming system is that of mixed farming in which cereal cropping is combined with livestock rearing comprising mainly cattle. Farm sizes are very small 0.65 hectares (ha) on average in the region (Tigray Bureau of Agriculture and Natural Resource Development-TBoANRD, 2003) - and decrease with the altitude. Productivity in cereal cropping is low with average yields below one ton per hectare (Pender et al., 2006). As a result, many farmers are subsistence farmers who face difficulties supporting their families, with an average of 5 to 6 members, from their farm. A three-stage stratified random sampling design was chosen to ensure representativeness of the sample and to cluster observations per district and sub-district. First, the ten districts in the catchment were stratified according to the agro-climatic zones: lowland, mid-highland and highland. One district was randomly selected from the two lowland zones, one district from the two upper highland zones and two from the six mid-highland zones. Second, in each selected district, two sub-districts were randomly selected. Third, 
in each selected sub-district, households were selected with a probability proportional to the sub-district population size. We used Agricultural Extension Agents' households list of the sub-district, and stratified households according to whether or not they received extension services program. The final sample included 730 households, of which 361 received extension services and 369 did not.

Model specification: Since our data set includes adopters of improved agricultural inputs and non-adopters, the dependent variable has many zero observations, such that a Tobit model is an appropriate model to handle such type of observations. The Tobit model can be specified as follows (Maddala, 1983):

$y_{i}=y_{i}^{*}$ if $y_{i}^{*}>0$ where $\left(y_{i}^{*}=\beta i x_{i}+\mu\right)$

$$
y_{i}=0
$$

where $y_{i}$ is the observed dependent variable, $y_{i}^{*}$ is a latent variable which is not observable, $x_{i}$ is a vector of factors affecting extension participation decisions, $\beta_{i}$ are parameters to be estimated and $\mu$ is the error term that is independently and normally distributed with $\mu \sim \mathrm{N}\left(\mu, \sigma^{\wedge} 2\right)$ (Greene, 2003). From the above formulation we can estimate the unknown parameters by maximizing the Tobit likelihood function (Maddala, 1983). Since the coefficients includes of a Tobit model includes both the effect of the covariate on the probability of adoption decision as well as the percentage change on the magnitude (intensity),it is not sensible to interpret the coefficients of a Tobit model, the same way we interpret a linear. Hence, we have to derive marginal effects (Anley, 2007). Following the proposed decomposition techniques of the Tobit model by McDonald \& Moffit (1980) the marginal effects of the explanatory variables can be decomposed into the decision to participate and the intensity effects. Accordingly, the change in the probability of extension participation as $x_{i}$ changes can be estimated as:

$\frac{\partial F(z)}{\partial\left(x_{i}\right)}=f(z) \frac{\beta_{i}}{\sigma}$

Where $f$ and $F$ are the density function and cumulative distribution function of $y_{i}^{*}$ respectively. Similarly, the marginal effect of an explanatory variable on the expected value of the dependent variable can be given by:

$\frac{\partial E\left(y_{i}\right)}{\partial\left(x_{i}\right)}=F(z) \beta_{i}$

Where $\frac{\beta_{i} x_{i}}{\sigma}$ is represented by $z$. Finally, the changes in the intensity of area covered by improved inputs and investment with respect to a unit change in an explanatory variable among participants can be estimated as follows (McDonald \& Moffitt, 1980):

$\frac{\partial E\left(y^{*}\right)}{\partial x_{i}}=\left\lceil 1-Z \frac{f(z)}{F(z)}-\left(\frac{f(z)}{F(z)}\right)^{2}\right\rceil$

Where $F(z)$ is the cumulative normal distribution of $z, f(z)$ is the value of the derivative of the normal curve at a given point (unit normal density), $z$ is the z-score for the area under normal curve, and $\beta i$ is a vector of Tobit maximum likelihood estimates. Since some of the explanatory variables can be potentially endogenous, one key methodological issue is how to address the causality issue and the resultant endogeneity problem. In some studies variables such farm, non-farm topical livestock and other endogeneous variables are used to explain the adoption decision of modern technologies and the how much to use (Alene et al., 2000; Shiferaw \& Tesfaye, 2006; Wubeneh \& Sanders, 2006).However, the direction of influence is not clear and results could be biased. In this study purely exogenous variables (variables that cannot be influenced by the adoption decision process), and lag variables (variables in the pre-adoption status, e.g. ox-ownership and non-farm income) are considered in the model specification. In order to increase our model estimation efficiency further, relatively large sample size drawn from three agro-ecological zones with bootstrapping estimation technique is used. The three agro-ecological representations, in addition to capturing the soil, temperature and rainfall variation across localities, the sample sites are also located at different distance from the local markets and regional markets. Hence, capturing all these characteristics will enable to have the required heterogeneity across our sampled households. 
The extension service variable could potentially be endogenous, particularly due to possible reverse causality or simultaneity, meaning those who adopt improved seeds and fertilizers could attract very frequent technical assistances. However, in our case, extension service is less likely to be endogenous for at least two reasons. Firstly, extension service has become almost universal service. Every farmer who wants the service can get through the scheduled meeting with development teams ${ }^{1}$ (constituting 15 farmers). Secondly, the content of the extension service is seasonal. It varies with the agricultural activities calendar and does not focus on a single technology, such as fertilizer and improved seeds. In other words, farmers are exposed to different technical services dealing with the farm management in general and not related to specific crops or technologies. Moreover, to the check the robustness of our exogeneity assumptions made, the inverse mills ratio (IMR) was estimated and added as an additional variable in the second stage equation and the coefficient of the IMR was found to be not different from zero, and so selection problem is not apparent in the model and as a result the intensity equation can be estimated using simple Tobit (without instrumetalizing the extension variable).

Explanatory variables included in the Tobit model are classified into five groups: household (household head age, gender, education, adult labour force availability, farm assets and resources (plot size, and oxen ownership), locational variables (four research site districts: Tanqua- lowland, Samre and Wukro Midhighlands; and Atsebi highland), institutional (access to extension service) and labour market. Their definition, expected sign (regressors only), mean and standard deviations are indicated in Table 1. Prior expectations about the relationship of the explanatory variables to technology adoption are based on theoretical underpinnings and from previous empirical results. We now briefly explain the independent variables and their expected direction of influence and the theoretical rationale. Price of inputs was not included in our specification, because there is no price variation across localities.

Household head age (AgeHHH): The sign of the household head age is very difficult to predict a priori. According to the adoption theory younger farmers are often more willing to innovate; younger farmers have a longer planning horizon and may be less risk averse than older and they found age to be negatively associated with technology adoption (Rogers, 1962; Zepeda, 1990).The human capital theory on the other hand, older farmers are more likely to have observed the benefits of previous modern technologies and more likely to be willing to adopt and try the new technology (Neill \& Lee, 2001). Hence, it is very difficult to know a prior.

Household head education (HHHedu): According to human capital theory, the years of school completed by the farm operator is expected to contribute to the ability to obtain information and apply inductive reasoning in making farm decisions (Schultz, 1972; Rahm \& Huffman, 1984). More educated and experienced farmers are in a better position to assess the relevance of new technologies (Marianoa et al., 2012).Hence, following the human capital theory, education is expected to be positively related with technology adoption.

Gender: This variable is included because as indicated in several poverty studies in developing countries, widows and generally female headed households to be among the poorest in the society (Mather et al., 2008; cited in Cunguara and Moder, 2011). Hence, male heads of households are expected to have better chance to adopt as compared with their female counter parts.

Adult labour force: A variable on the number of adult members was included because household size and composition influence labour availability (Doss, 2006). Hence, it is equally plausible that the labour intensive nature of the technology adoption and extension program would require more labour and households with relatively better labour supply, ceteris paribus, to be early adopters.

Household assets: the variables included under this category are plot size in tsemad (one tsemad-quarter a hectare) and oxen ownership, expressed in lagged form. As one would expect, larger cropped area are usually associated with higher crop income. Similarly, oxen ownership is a very important and productive asset in the farming context and more likelihood of taking some risks (Cunguara \& Moder, 2011).

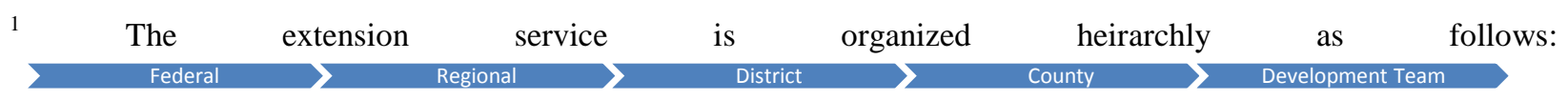


Non-farm income: Finally, non-farm and farm sectors can be linked via investment. For instance, part of the income saved from the farm or non-farm activities may be used as source of investment for non-farm or farm investment respectively (Oseni \& Winters, 2009). On the other hand, non-farm income might be used to finance farm activities, thereby encouraging farm investment and labor allocation (Davis et al., 2002; Maertens, 2009). Alternatively, it may result in less time and investment being devoted to the management of the farm business (McNally, 2002; Phimister \& Roberts, 2006). Hence, it is very difficult to know a prior.

Extension service: Extension service as source of information and technology is hypothesized to have a positive influence on adoption of technologies.

Access to market: In order to understand the influence of market access on participation in the extension program and adoption of modern agricultural technologies four area dummy variables are included. These four district dummies are drawn from the different agro-ecological zones of the region and related attribute differences that may exist across these research sites.

\section{Results and discussion}

Descriptive statistics: Table 1 presents the definition of variables (both outcome and explanatory) used in the model estimation and their descriptive statistics. As indicated in the table the average land holding size is 4.48 tsemad (almost 1 hectare) which is above the regional average of 0.5 hectare. Despite a long history of promotion of fertilizer and improved seed technologies in Ethiopia, only $16 \%$ and $37 \%$ of the farm land are covered by improved seeds and fertilizer respectively, which is higher than the national average of for improved seeds (3\% national average) and 32\% for fertilizer. The average income of the household is estimated to be Birr 9635 (US\$ $732^{2}$ ) which is very low as compared with the national average income (US\$2025) for a household with family size of 5.4 persons. Non-farm income contributed $31 \%$ of the household income. The average age of the sample households was found to be 44 years, and only $36 \%$ of the household heads were literate, which is not favourable for technology adoption (assuming illiterate household heads are resistant to new technology adoption).Out of the sampled households, $49 \%$ were extension participants and had an average of 3.6 years of experience in the extension program, which is reasonable time to categorize a household as a modern technology adopter.

Econometrics results: The results of the Tobit model for fertilizer and improved seed intensity and the total budget spent on these two technology packages are summarized in Tables 2, 3 and 4 respectively. Out of the 11 variables ten (model 1) seven(model 2) eleven (model 3) of them were found to be significant and with the hypothesized sign. The estimated coefficient for Age (AgeHHH) as a proxy for farm experience was found to be consistently negative in the three models, and significant at $1 \%$ level of significance in fertilizer and total input application models (not significant for improved seeds). As evidenced by various studies the relationship between technology adoption and age has remained mixed. Lapar \& Pandey (1999), in their study of adoption decisions of soil conservation in uplands in the Philippines; Baidu-Forson (1999) in his study on the adoption of land enhancing technology in the Sahel; Fufa \& Hassan (2006) and Chirwa (2005) in their study of fertilizer adoption in Ethiopia and hybrid seed for Malawi found a negative relationship respectively. This implies that, as farmers grow older, they become more risk averse and less willing to adopt new farming technologies. On the other hand, Polson \& Spencer (1991) and Abay \& Admassie (2004) found a positive relationship between age and improved cassava variety adoption in Nigeria and chemical fertilizer adoption in Ethiopia respectively. Hence, age when taken as proxy for farm experience (human capital theory) it will be positive; whereas when older farmers as having very short planning horizon and high risk averse age can be negatively associated with technology adoption (Zepeda, 1990). Hence, the sign of the household head age is very difficult to predict a priori.

\footnotetext{
${ }^{2} 1$ US $\$=15$ Ethiopian Birr (during the survey period)
} 
Table 1: Definition of variables and descriptive statistics summary

\begin{tabular}{|c|c|c|c|c|}
\hline Variable & Variable description & $\begin{array}{l}\text { Expected }^{3} \\
\text { sign }\end{array}$ & Mean & SD \\
\hline \multicolumn{5}{|c|}{ Outcome variables } \\
\hline prportfert & Percentage of the total plot covered by fertilizer & & 0.37 & 0.36 \\
\hline propseed & $\begin{array}{l}\text { Percentage of the total plot covered by improved seeds } \\
\text { varieties }\end{array}$ & & 0.16 & 0.27 \\
\hline Timproved & $\begin{array}{l}\text { Total money spent by the household for improved } \\
\text { inputs }\end{array}$ & & 323.00 & 383.00 \\
\hline \multicolumn{5}{|c|}{ Household characteristics } \\
\hline AgeHHH & Age of the household head & $+/-$ & 44.00 & 14.60 \\
\hline Gender & Gender of the household head & + & 0.73 & 0.44 \\
\hline Adult & Adult labor force in the household & + & 2.75 & 1.41 \\
\hline Edu & 1 if household head is literate & + & 0.36 & 0.48 \\
\hline \multirow[t]{2}{*}{ Fsize } & Average family size of the household & & 5.4 & 2.27 \\
\hline & Farm characteristics & & & \\
\hline plotsize & Land holding size in Tesemad ${ }^{4}$ & $+/-$ & 4.38 & 3.37 \\
\hline Livestock & Value of the livestock holding & & 116.66 & 313.74 \\
\hline Ox-Lag & Number of oxen prior to the adoption year & + & 1.37 & 1.16 \\
\hline TotalI & Total income of the household & & 8055 & 11470 \\
\hline cropincome & Total crop income of the household & & 5136.68 & 7150.7 \\
\hline livestockI & Livestock income of the household & & 1977.58 & 3356 \\
\hline propseed & $\%$ of total area covered by improved seed & & 0.16 & 0.27 \\
\hline prportfert & $\%$ of total area covered by fertilizer & & 0.37 & 0.36 \\
\hline \multirow[t]{2}{*}{ Timproved } & Total value of modern inputs in Birr & & 323.93 & 383.27 \\
\hline & Locational variables & & & \\
\hline Tanqua & District 1 & $+/-$ & 0.24 & 0.42 \\
\hline Samre & District 2 & $+/-$ & 0.32 & 0.46 \\
\hline Wukro & District 3 & $+/-$ & 0.21 & 0.40 \\
\hline \multirow[t]{2}{*}{ Atsebi } & District 4 & $+/-$ & 0.21 & 0.41 \\
\hline & Institutional variables & & & \\
\hline Paryear & Average years in the extension program & & 3.6 & 1.8 \\
\hline \multirow[t]{2}{*}{ Extenp01 } & 1 if household is participant & + & 0.49 & 0.50 \\
\hline & Labor market & & & \\
\hline TotalNFI_ & Total non-farm income & $+/-$ & 2523.00 & 8554.39 \\
\hline
\end{tabular}

Source: Author's calculation from survey data

The variable gender (where male is 1) was found to be positively and significantly related with the three outcome variables. This variable (excluding district dummies) was found the second most important next to plot size influencing adoption and intensity. Which shows that, being male increases the probability of adoption of the technologies and increases the percentage of plot size to be covered by improved inputs and total spending. This indicates that, females in general and female headed households in particular have

\footnotetext{
${ }^{33}$ Signs are assigned only for those variables used in the model estimation. For others as they are not going to be used in model estimation they cannot be tested and signs could not be assigned.

${ }^{4} 1$ tsemad $=1 / 4$ of a hectare
} 
remained marginalized in the fight against poverty alleviation, access to new technologies and other important development inputs. As a result poverty profile in Ethiopia reveals that female-headed households tend to be poorer and more constrained by resource availability (Bekele \& Worku, 2008). Consistent with our expectation education (literacy status of the household) was positively and significantly related with adoption of fertilizer and total input purchase, but not in improved seeds (model 2). Similar results were echoed by Abay \& Admassie (2004) and Alene et al. (2000).

Table 2: Tobit model results of the adoption and intensity of use (\% of area covered) of fertilizer input-model 1

\begin{tabular}{|c|c|c|c|c|c|c|}
\hline & $\begin{array}{l}\text { ML- } \\
\text { estimate }\end{array}$ & SE & p-value & $\begin{array}{l}\text { Probability } \\
\text { uncensored }\end{array}$ & $\begin{array}{l}\text { Conditional or } \\
\text { being uncensored }\end{array}$ & $\begin{array}{l}\text { Unconditional } \\
\text { expected value }\end{array}$ \\
\hline AgeHHH & -0.003 & 0.001 & $0.001^{* * *}$ & -0.001 & -0.003 & -0.002 \\
\hline Gender & 0.113 & 0.040 & $0.005^{* * *}$ & 0.053 & 0.127 & 0.075 \\
\hline Adult & 0.020 & 0.010 & $0.058^{*}$ & 0.009 & 0.022 & 0.014 \\
\hline Edu & 0.047 & 0.028 & $0.091^{*}$ & 0.023 & 0.051 & 0.033 \\
\hline plotsize & 0.131 & 0.035 & $0.000^{* * *}$ & 0.064 & 0.142 & 0.091 \\
\hline Ox-Lag & 0.023 & 0.035 & $0.046^{* *}$ & 0.011 & 0.025 & 0.016 \\
\hline TotalNFI_lag & -0.003 & 0.004 & 0.389 & -0.001 & -0.003 & -0.002 \\
\hline Extenp01 & 0.050 & 0.023 & $0.30^{* *}$ & 0.024 & 0.054 & 0.035 \\
\hline Tanqua & 0.345 & 0.055 & $0.000^{* * *}$ & 0.198 & 0.307 & 0.268 \\
\hline Samre & 0.537 & 0.049 & $0.000^{* * *}$ & 0.311 & 0.461 & 0.412 \\
\hline Wukro & 0.309 & 0.056 & $0.000^{* * *}$ & 0.177 & 0.275 & 0.241 \\
\hline Atsebi & Omitted & - & - & - & - & - \\
\hline \multicolumn{3}{|c|}{ Wald chi2 (11) } & \multicolumn{2}{|c|}{339.87} & & \\
\hline \multicolumn{3}{|c|}{ Censored observations } & \multicolumn{2}{|c|}{287} & & \\
\hline \multicolumn{3}{|c|}{ Uncensored observations } & \multicolumn{2}{|c|}{447} & & \\
\hline \multicolumn{3}{|c|}{ Predicted probability of $Y>$ limit } & 0.7 & & & \\
\hline
\end{tabular}

Significant differences are indicated with ${ }^{*} \mathrm{p}<0.1 ;{ }^{* *} \mathrm{p}<0.05 ;{ }^{* * *} \mathrm{p}<0.01$

Source: Author's calculation from survey data

The adult labour force variable, measured by the number of members within the working age in the household, was found to be positively and significantly related with the three outcome variables, indicating that farmers with larger labour force are more likely to increase the adoption of improved technologies. The result indicates that improved seeds and fertilizer applications may require more labour and generally intensive field management. Similar results were reported by Noltze et al. (2012) in their study on adoption of system technologies in Timor Leste. As expected, the most important wealth (asset) indicator variables plot size and oxen ownership (in its lag form to minimize the potential endogeneity problem) were found to have positive and significant effect in the three models. Plot size (excluding district dummies) plot size was found to be the most important variable. Each additional tsemad of land increased the probability of adoption of fertilizer by $9 \%$, and on average, each additional tsemad of land cultivated has increased the number of tsemad of land covered by fertilizer by $3.2 \%$ for the entire sample and 2.8 for users. The results are supported by similar studies on the effect of farm size and technology adoption, where Shortle \& Maranowski (1986), Jamnick \& Klindt (1985) and Lee \& Stewart (1993) have all concluded that the bigger the plot size, the greater the chances of conservation agriculture being fully adopted. 
Table 3: Tobit model results of the adoption and intensity of use ( $\%$ of area covered) of improved seeds-model 2

\begin{tabular}{|c|c|c|c|c|c|c|}
\hline & $\begin{array}{l}\text { ML- } \\
\text { estimate }\end{array}$ & SE & p-value & $\begin{array}{l}\text { Probability } \\
\text { uncensored }\end{array}$ & $\begin{array}{l}\text { Conditional on } \\
\text { being uncensored }\end{array}$ & $\begin{array}{l}\text { Unconditional } \\
\text { expected value }\end{array}$ \\
\hline AgeHHH & -0.000 & 0.001 & 0.924 & -0.000 & -0.000 & -0.000 \\
\hline Gender & 0.108 & 0.055 & $0.052^{*}$ & 0.092 & 0.028 & 0.032 \\
\hline Adult & 0.027 & 0.014 & $0.062^{*}$ & 0.023 & 0.007 & 0.008 \\
\hline Edu & 0.050 & 0.039 & 0.196 & 0.045 & 0.014 & 0.016 \\
\hline plotsize & 0.102 & 0.043 & $0.017^{* *}$ & 0.090 & 0.028 & 0.032 \\
\hline Ox-Lag & 0.061 & 0.019 & $0.002^{* * *}$ & 0.054 & 0.017 & 0.020 \\
\hline TotalNFI_lag & -0.002 & 0.005 & 0.726 & -0.001 & -0.001 & -0.000 \\
\hline Extenp01 & 0.069 & 0.041 & $0.092^{*}$ & 0.061 & 0.019 & 0.022 \\
\hline Tanqua & -0.653 & 0.091 & $0.000^{* * *}$ & -0.425 & -0.146 & -0.141 \\
\hline Samre & 0.038 & 0.060 & 0.527 & 0.033 & 0.010 & 0.012 \\
\hline Wukro & 0.099 & 0.053 & $0.063^{*}$ & 0.090 & 0.028 & 0.034 \\
\hline Atsebi & Omitted & - & - & - & - & - \\
\hline \multicolumn{3}{|l|}{ Wald chi2 (11) } & \multicolumn{2}{|l|}{231.63} & & \\
\hline \multicolumn{3}{|c|}{ Censored observations } & \multicolumn{2}{|c|}{476} & & \\
\hline \multicolumn{3}{|c|}{ Uncensored observations } & \multicolumn{2}{|c|}{258} & & \\
\hline \multicolumn{3}{|c|}{ Predicted probability of $Y>$ limit } & 0.32 & & & \\
\hline
\end{tabular}

Significant differences are indicated with ${ }^{*} \mathrm{p}<0.1 ;{ }^{* *} \mathrm{p}<0.05 ;{ }^{* * *} \mathrm{p}<0.01$

Source: Author's calculation from survey data

Table 4: Tobit model results of the adoption and intensity of use of Total value of improved inputsmodel 3

\begin{tabular}{|c|c|c|c|c|c|c|}
\hline & $\begin{array}{l}\text { ML- } \\
\text { estimate }\end{array}$ & SE & p-value & $\begin{array}{l}\text { Probability } \\
\text { uncensored }\end{array}$ & $\begin{array}{l}\text { Conditional } \\
\text { being uncensore }\end{array}$ & $\begin{array}{l}\text { Unconditional } \\
\text { expected value }\end{array}$ \\
\hline AgeHHH & -0.018 & 0.010 & $0.074^{*}$ & -0.001 & -0.013 & -0.016 \\
\hline Gender & 1.311 & 0.388 & $0.000^{* * *}$ & 0.089 & 0.922 & 1.170 \\
\hline Adult & 0.161 & 0.069 & $0.021^{* *}$ & 0.009 & 0.119 & 0.148 \\
\hline Edu & 0.417 & 0.239 & $0.082^{*}$ & 0.023 & 0.309 & 0.382 \\
\hline plotsize & 1.827 & 0.326 & $0.000^{* * *}$ & 0.106 & 1.345 & 1.671 \\
\hline Ox-Lag & 0.455 & 0.096 & $0.000^{* * *}$ & 0.026 & 0.335 & 0.416 \\
\hline TotalNFI_lag & -0.043 & 0.023 & $0.067^{*}$ & -0.002 & -0.031 & -0.039 \\
\hline Extenp01 & 0.368 & 0.197 & $0.62^{*}$ & 0.021 & 0.271 & 0.336 \\
\hline Tanqua & 1.145 & 0.474 & $0.016^{* *}$ & 0.057 & 0.876 & 1.063 \\
\hline Samre & 3.130 & 0.425 & $0.000 * * *$ & 0.146 & 2.451 & 2.915 \\
\hline Wukro & 1.769 & 0.444 & $0.000^{* * *}$ & 0.080 & 1.388 & 1.657 \\
\hline Atsebi & Omitted & - & - & - & - & - \\
\hline \multicolumn{3}{|c|}{ Log of likelihood } & \multicolumn{2}{|c|}{600.92} & & \\
\hline \multicolumn{3}{|c|}{ Censored observations } & \multicolumn{2}{|c|}{203} & & \\
\hline \multicolumn{3}{|c|}{ Uncensored observations } & \multicolumn{2}{|c|}{531} & & \\
\hline \multicolumn{3}{|c|}{ Predicted probability of $Y>$ limit } & \multicolumn{2}{|c|}{0.91} & & \\
\hline
\end{tabular}

Significant differences are indicated with ${ }^{*} \mathrm{p}<0.1$; ${ }^{* *} \mathrm{p}<0.05 ;{ }^{* * *} \mathrm{p}<0.01$

Source: Author's calculation from survey data 
Non-farm income has a negative but insignificant (except model 3) effect on the three models. A plausible explanation for this is that there are little or no opportunities for off-farm employment in the study area and families rely heavily on farm income to acquire many of the required inputs. The results are consistent with the findings of Holden et al. (2004) in Ethiopia where access to rural non-farm activities was found increase soil erosion and land degradation suggesting a drop in agricultural total factor productivity and Pfeiffer et al. (2009) for Mexico and Huang et al. (2009) for China who reported a negative relationship between non-farm income and household calorie intake respectively. Access to extension service (as dummy variable) showed a positive and significant effects on the three models, and these results are consistent with our expectations. Next to plot size and gender variables extension service was found to be most important variable in influencing the adoption decision of farmers. The results are consistent with the findings of Alene et al. (2000). Farmers in Samre district (model 1 and model 3) and farmers in district Wukro (model 2) were found to have high probability of adoption and more likely to have higher percentage of their land to be covered by improved seeds and fertilizer. This has an important implication for targeting areas for further expansion of new technologies.

\section{Conclusion and Recommendations}

This study examined the impact of agricultural extension service in the Tigray region the northern part of Ethiopia. Using agro-ecologically disaggregated detailed data collected from small-scale farm farmers in 2009, Tobit model was estimated for fertilizer (\% of area covered), improved seeds (\% of area covered), and total value spent on improved inputs. Estimated results showed that the program importantly contributed to rising household input adoption and input use intensity in the region. In addition to, the policy instrument (agricultural extension service) variable, demographic characteristics variables such as gender, adult labour force, age and education of the household head, and wealth indicator oxen ownership and plot size were found to be important factors significantly affecting the adoption decision of the households. Of particular interest are the findings of importance of plot size gender and extension services in generating higher adoption rates. The policy implication is the need to bridge the gap resulting from land size (wealth difference) through effective and well-targeted credit scheme intervention so as to encourage resource-poor farmers in the adoption process. The second policy implication is still narrowing the gender gap in the adoption of technologies. The third policy implication is, given the significant role played by extension in technology adoption decision and intensity; it clearly indicates the need to expand the extension outreach, both in terms of area and household coverage.However, since our findings are based on cross sectional data, the interpretation and conclusion reached should be taken with caution.

Acknowledgement: The author, wish to express his profound gratitude to VLIR-UOS (Belgium) for the full and generous financial support for the study through the MU-IUC program. The author, also sincerely and duly recognize my mentor as postdoctoral fellow, Daniel Makina of UNISA, for his meticulous comments and creating an enabling work environment. Finally, all the research site farmers who patiently seated for hours to answer the detailed interviews and the enumerators who worked tirelessly to collect the data are also appreciated.

\section{References}

Abate, H. (2007). Review of Extension Systems Applied in Ethiopia with Special emphasis to the Participatory Demonstration and Training Extension System. Food and Agriculture Organization of the United Nations (unpublished), Addis Ababa, Ethiopia.

Abay, A. \& Assefa, A. (2004).The role of education on the adoption of chemical fertiliser under different socioeconomic environments in Ethiopia. Agricultural Economics, 30(3), 215-228.

Abdulai, A. \& Huffman, W. E. (2005). The diffusion of new agricultural technologies: the case of crossbred-cow technology in Tanzania. American Journal of Agricultural Economics, 87(3), 645-659.

Abebe, G. K., Bijman, J., Pascucci, S. \& Omta, O. (2013). Adoption of improved potato varieties in Ethiopia: The role of agricultural knowledge and innovation system and smallholder farmers' quality assessment. Agricultural System, 122, 22-32.

Adeoti, A. I. (2009). Factors Influencing Irrigation Technology Adoption and Its Impact on Household Poverty in Ghana. Journal of Agriculture and Rural Development in the Tropics and Subtropics, 109(1)51-63. 
Alene, A. D., Poonyth, D. \& Hassan, R. M. (2000). Determinants of adoption and intensity of use of improved maize varieties in the central highlands of Ethiopia: a Tobit analysis Agrekon. Agricultural Economics Research, Policy and Practice in Southern Africa, 39(4), 633-643.

Anley, Y., Bogale, A. \& Hailegabriel, A. (2007). Adoption decision and use intensity of soil and water conservation measures by smallholder subsistence farmers in Dedo district. Western Ethiopia Land Degradation and Development, 18(3), 289-302.

Baidu-Forson, J. (1999). Factors influencing adoption of land-enhancing technology in the Sahel: lessons from a case study in Niger. Agricultural Economics, 20(3), 231-239.

Bekele, E. \& Worku, Z. (2008). Women Entrepreneurship in Micro, Small and Medium Enterprises: The Case of Ethiopia. Journal of International Women's Studies, 10(2), 2-19.

Block, S. (1999). Agriculture and economic growth in Ethiopia: growth multipliers from a four sector simulation model. Agricultural Economics, 20(3), 241-252.

Caswell, M. \& Zilberman, D. (1985). The Choices of Irrigation Technologies in California American. Journal of Agricultural Economics, 67(2), 224-334.

Chirwa, E. W. (2005). Adoption of fertiliser and hybrid seeds by smallholder maize farmers in Southern Malawi. Development Southern Africa, 22(1), 1-12.

Cunguara, B. \& Moder, K. (2011). Is agricultural extension helping the poor? Evidence from rural Mozambique. Journal of African Economies, 20(4), 562-595.

Davidson, B. (1960). Africa in History. London, Pladin Garton Books.

Davis, B., Reardon, T., Stamoulis, K. \& Winters, P. (2002). Promoting farm/off-farm linkages for rural development Case Studies from Africa and Latin America. Food and Agricultural organization of the United Nations.

Davis, K., Swanson, B. \& Amudavi, D. (2009). Review and Recommendations for Strengthening the Agricultural Extension System in Ethiopia, International Food Policy Research Institute, Sustainable solutions for ending hunger and poverty, Washington D.C.

Dinar, A. \& Yaron, D. (1990). Influence of Quality and Scarcity of Inputs on the Adoption of Modern Irrigation Technologies. Western Journal of Agricultural Economics, 15(2), 224-233.

Doss, C. R. (2006). Analysing technology adoption using micro-studies: limitations, challenges, and opportunities for improvement. Agricultural Economics, 34(3), 207-219.

Food and Agriculture. (2014). FAO Statistical YearBook 2014 Africa, Food and Agriculture Organization of the United NationsRegional Office for Africa Accra, 2014.

Feder, G. (1980). Farm Size, Risk Aversion and the Adoption of New Technology under Uncertainty Oxford. Economic paper, 32(2), 263-283.

Feder, G., Just, R. E. \& Zilberman, D. (1985). Adoption of Agricultural Innovations in Developing Countries. $A$ Survey Economic Development and Cultural Change, 33(2), 255-298.

Federal Democratic Republic of Ethiopia (FDRE), Ministry of Finance and Economic Development (MOFED). (2002). Ethiopia: Sustainable Development and Poverty Reduction Program", Addis Ababa, Ethiopia.

Food and Agriculture Organization of the United Nations. (2013). FAO STATISTICAL YEARBOOK-2013: World food and agriculture", Rome.

Fufa, B. \& Hassan, R. M. (2006). Determinants of fertilizer use on maize in Eastern Ethiopia: A weighted endogenous sampling analysis of the extent and intensity of adoption Agrekon: Agricultural Economics Research. Policy and Practice in Southern Africa, 45(1), 38-49.

Greene, W. H. (2003). Econometric Analysis (5 ${ }^{\text {th }}$ edition). Pearson Education, Inc., Upper Saddle River, New Jersey.

Henao \& Baanante. (1999). Estimating rates of nutrient depletion in soils of agricultural lands of Africa, Muscle Shoals. IFDC. ISBN 0-88090-125-X.

Holden, S., Shiferaw, B. \& Pender, J. (2004). Off-farm Income, Household Welfare and Sustainable Land Management in a Less -favoured Area in the Ethiopian Highlands. Food Policy, 29(4), 369-392.

Huang, J., Wu, Y. \& Rozelle, S. (2009). Moving off the farm and intensifying agricultural Production in Shandong: a case study of rural labor market linkages in China. Agricultural Economics, 40(2), 203218.

Huffman, W. E. (1977). Allocative Efficiency: The Role of Human Capital. The Quarterly Journal of Economics, 91(1), 59-79.

Hurni, H. (1988). Degradation and conservation of the resources in the Ethiopian Highlands: part 2 climate, soil and water Mountain. Research and Development, 8(2/3), 123-130. 
Jamnick, S. K. \& Klindt, T. H. (1985). An analysis of 'no-tillage' practice decisions. Department of Agricultural Economics and Rural Sociology, University of Tennessee, USA.

Kidanemariam, G. (2013). Essays on income diversification and agricultural extension: a case from northern Ethiopia, PhD thesis (unpublished), Katholieke Universiteit Leuven, Heverlee, Belguim.

Lal, R. (1995). Erosion-Crop Productivity Relationships for Soils of Africa. Soil Science Society of American Journal, 59(3), 661-667.

Lapar, M. L. A. \& Pandey, S. (1999). Adoption of soil conservation: the case of the Philippines uplands. Agricultural Economics, 21(3), 241-256.

Lee, L. K. \& Stewart, W. H. (1983). Land-ownership and the adoption of minimum tillage. American Journal of Agricultural Economics, 68(2), 256-264.

Maddala, G. S. (1983). Limited-dependent and qualitative variables in econometrics. Cambridge University Press, New York, USA.

Maertens, M. (2009). Horticulture exports, agro-industrialization, and farm-off-farm linkages with the smallholder farm sector: evidence from Senegal. Agricultural Economics, 40(2), 219-229.

Marianoa, M. J., Villano, R. \& Fleming, E. (2012). Factors influencing farmers' adoption of modern rice technologies and good management practices in the Philippines. Agricultural Systems, 110, 41-53.

Mather, D., Cunguara, B. \& Boughton, D. (2008). Household Income and Assets in Rural Mozambique, 20022005: Can Pro-Poor Growth Be Sustained? Working Paper 66E, Ministry of Agriculture, Maputo.

McDonald, J. F. \& Moffit, R. A. (1980). The use of Tobit analysis. Review of Economics and Statistics, 62(2), 318321.

McNally, S. (2002). Are other gainful activities on farms good for environment? Journal of Environmental Management, 66(1), 57-65.

Neill, S. \& Lee, D. E. (2001). Explaining the Adoption and Dis-adoption of Sustainable Agriculture: The Case of Cover Crops in Northern Honduras. Economic Development and Cultural Change, 49(4), 793-820.

Noltze, M., Schwarze, S. \& Qaim, M. (2012).Understanding the adoption of system technologies in smallholder agriculture: The system of rice intensification (SRI) in Timor Leste. Agricultural Systems, 108, 64-73.

Oseni, G. \&Winters, P. (2009). Rural off-farm activities and agricultural crop production in Nigeria. Agricultural Economics, 40(2), 189-201.

Pender, J., Place, F. \& Ehui, S. (2006). Strategies for sustainable land management in the East African highlands, Washington, D.C.: International Food Policy Research Institute.

Pfeiffer, L., Lopez-Feldman A. \& Taylor J. E. (2009). Is off-farm income reforming the farm? Evidence from Mexico. Agricultural Economics 40(2), 125-138.

Phimister, E. \& Roberts, D. (2006). The Effects of off-farm work on the intensity of agricultural Production. Environmental and Resource Economics, 34(4), 493-515.

Polson, R. A. \& Spencer, D. S. C. (1991). The Technology adoption process in subsistence agriculture: the case of cassava in South-western Nigeria. Agricultural Systems, 36, 65-8.

Putler, D. S. \& Zilberman, D. (1988). Computer Use in Agriculture: Evidence from Tulare County, California. American Journal of Agricultural Economics, 70(4), 790-802.

Rahm, M. R. \& Huffman,W. E. (1984).The Adoption of Reduced Tillage: The Role of Human Capital and Other Variables American. Journal of Agricultural Economics, 66(4), 405-13.

Rogers, E. M. (1962). Diffusion of innovations. Free Press of Glencoe, New York.

Rogers, E. M. (1983). Diffusion of innovations. $3^{\text {rd }}$ Edition, Free Press, New York.

Schultz, T. W. (1972). The Increasing Economic Value of Human Time. American Journal of Agricultural Economics, 54(5), 843-850.

Shiferaw, F. \&Tesfaye, Z. (2006). Adoption of improved maize varieties in Southern Ethiopia: Factors and strategy options. Food Policy, 31(5), 442-457.

Shortle, J. S. \& Maranowski, J. A. (1986). Effect of risk perceptions and other characteristics of farmer and farm operations on the adoption of conservation tillage practices. Department of Agricultural Economics, Pennsylvania State University, USA.

Spielman, D. J., Byerlee, D., Alemu, D. \& Kelemework, D. (2010). Policies to promote cereal intensification in Ethiopia: The search for appropriate public and private roles. Food Policy, 35(3), 185-194.

Sunding, D. \& Zilberman, D. (2001). The agricultural innovation process: research and technology adoption in a changing agricultural sector. In: Gardner, B.L., Rausser, G.C. (Eds.), Handbook of Agricultural Economics, Volume 1A Agricultural Production. Elsevier, New York.

Taddese, G. (2001).Land Degradation: A challenge to Ethiopia. Environmental Management, 27(6), 815-824. 
Tigray Bureau of Agriculture and Natural Resource Development-TBoANRD. (2003). Integrated Household Extension Intervention Program in Tigray vol. 1.Mekelle, Tigray, Ethiopia.

Tomich, P., Kilby, P. \& Johnston, F. (1995).Transforming Agrarian Economies Cornell University Press, Ithaca, NY.

United Nations. (2004). World Projection to 2300 Department of Economic and Social Affairs: Population Division, ST/ESA/SER.A/236 New York.

Wubeneh, N. G. \& Sanders, J. H. (2006). Farm-level adoption of Sorghum technologies in Tigray, Ethiopia. Agricultural Systems, 9, 122-134.

Zeller, M., Diagne, A. \& Mataya, C. (1998).Market access by smallholder farmers in Malawi: implications for technology adoption, agricultural productivity and crop income. Agricultural Economics, 19(1-2), $219-29$.

Zepeda, L. (1990). Predicting Bovine Somatotropine Use by California Dairy Farmers. Western Journal of Agricultural Economics, 15(1), 55-62. 